\title{
FREE CASH FLOWS, MANAGEMENT OWNERSHIP, DIVIDEND POLICY, AND DEBT POLICY
}

\author{
Ardhya Yudistira Adi Nanggala ${ }^{1}$ \\ Email:ardhyananggala@gmail.com
}

\begin{abstract}
This study aims to identify and examine empirically effect of free cash flows, managerial ownership and dividend policy on debt policy. This study uses secondary data taken from the company's financial statements on the Indonesia stock exchange which are available for consecutive reporting from 2012 to 2017. Samples were taken by purposive sampling with certain criteria. Number of samples in this study 132 firm years. The method of data analysis uses multiple linear regression analysis. The results showed that: free cash flow and managerial ownership had a significant positive effect on debt policy. Dividend policy has a significant negative effect on debt policy.
\end{abstract}

Keywords: free cash flows, managerial ownership, dividend policy, and debt policy

\section{INTRODUCTION}

A company that continues to grow always wants to gain profits or avoid losses, so companies need support of fast and continuous information in form of accounting information in form of financial statements. In a simple sense, financial statements are reports that show company's financial condition at this time or in a certain period. In financial statements presented amount of corporate profits that may not come from company's operating activities, although sometimes cash flow is negative. Growing companies often experience this phenomenon. Especially when companies reinvest their profits in their business, so they can maintain / maintain and enhance company growth.

Capital structure is a mix between proportion of external funding sources in form of long-term debt and equity. Companies are more likely to use internal funding sources, namely from retained earnings and depreciation in advance, rather than external funds in funding activities. Only if company does not have adequate internal funds, external funds are chosen as an alternative. If external funds are needed, companies are more likely to use debt than equity.

Debt is an alternative source of corporate funding, where use of debt can benefit company compared to use of own capital. Debt funding has advantage that interest paid on debt can be a tax deduction, while dividends paid on shares are not

${ }_{1}$ Corresponding Author: Faculty of Economics, University of Abdurachman Saleh Situbondo, Indonesia 
tax deductible. This reduces relative cost of debt and returns on fixed debt, so that shareholders do not participate in receiving company profits if company achieves extraordinary success. But debt also has a weakness, namely use of large amounts of debt increases financial risk.

Debt policy is a policy taken by financial management in order to obtain sources of funding from third parties to finance company's operational activities. Debt policy is one of important decisions faced by managers regarding funding decisions, because this decision affects value of company so that it affects prosperity of shareholders.

There are several variables that affect a company's debt policy including management ownership, institutional ownership, dividend policy, free cash flow, asset structure, profitability, company size, company growth, and business risk. However, this research is limited to research only on free cash flow, management ownership, and dividend policy.

Free cash flow according to Brigham and Houston (2006) is cash flow available to be distributed to all investors (shareholders and debt holders) after company places all of its investment in long-term assets and working capital needed to maintain ongoing operations. Thus, free cash flow can be interpreted as corporate cash that can be distributed or distributed to shareholders or creditors that are not used for working capital or investment in fixed assets.

Management ownership is level of share ownership of management who actively participates in decision making, for example directors and commissioners (Wahidahwati 2002). By increasing share ownership by managers, managers can feel directly consequences of decision making so that managers may not act opportunistically anymore (Masdupi 2005).

Management ownership of corporate securities can equate management interests with external parties and reduce role of debt as a mechanism to minimize agency costs. Increased ownership by management, causing management to be more careful in using debt and avoid opportunistic behavior because they share consequences of their actions, so they tend to use low debt (Faisal 2004).

For investors or shareholders, dividends are one of benefits they get besides other benefits in form of capital gains. In general, dividends can be interpreted as parts distributed by issuer to each shareholder. This dividend policy has an influence on level of debt use of a company. A stable dividend policy causes company to have to provide some funds to pay fixed amount of dividends so that company's funding needs increase.

Existence of a fixed dividend payment causes a permanent funding requirement each year so that company's funding needs increase. Companies that have high dividend payout ratios prefer funding with their own capital because dividend payments increase company liabilities and dividend payments are generally made after company makes payments on interest and debt repayments. Therefore, managers are more careful and efficient in using debt.

Research by measuring free cash flow, management ownership, and dividend policy as an independent variable that affects a company's debt has been done by several researchers before.

Research on effect of dividend policy on debt policy has been carried out by Indahningrum and Ratih (2009). Results of his research show that dividend policy 
has a positive effect. Results of study are different from research of Yeniatie and Nicken (2010) which shows that dividend policy has no effect on debt policy.

Research on effect of management ownership on debt policy has been conducted by Susilawati et al. (2012). Results of his research indicate that management ownership does not significantly influence debt policy. Results of this study differ from Susanto (2011) research which shows that management ownership influences debt policy.

Research on effect of free flow Free cash flow on debt policy has been carried out by Hasugian (2010) Free cash flow has no significant effect on Debt to Equity Ratio. Results of this study are not consistent with Susilawati et al. (2012) study which states that free cash flow has a significant positive effect on debt policy.

Previous studies regarding free cash flow, management ownership, and dividend policy. Indicates existence of inconsistent research results, so authors are interested in reexamining these variables. Researchers are interested in conducting research on manufacturing companies because manufacturing companies are companies that sell their products starting from production process that is not interrupted from purchase of raw materials followed by processing of raw materials to become products that are ready and sold by company itself so that source of funds there is a long-standing bound to long-term assets. Manufacturing companies need more long-term funding sources to finance company's operations and one of them is to use debt. In addition, manufacturing companies have a high risk in their business activities due to internal and external factors that influence decision making process regarding policies that are implemented so that it is interesting to be investigated.

\section{LITERATURE REVIEW}

\subsection{Pecking Order Theory}

Myers and Maljuf (1984) in Pecking Order Theory stated that corporate funding decisions have a hierarchy. Companies are more likely to use internal funding sources, namely from retained earnings and depreciation in advance, rather than external funds in funding activities. Only if company does not have adequate internal funds, external funds are chosen as an alternative. If external funds are needed, companies are more likely to use debt than equity Siregar and Utama (2005). In theory of Pecking Order Theory there are several assumptions used Mayangsari (2003), namely: 1) Companies tend to choose internal funding first (retained earnings and depreciation) so that external funding (debt and stock) is last alternative, 2) If company uses funds externally then selection is made tiered starting from safest to most risky. As starting from debt securities, convertible bonds, preferred shares and last of ordinary shares, 3) A strict dividend policy where management sets amount of dividend payments and target dividend payout ratio (DPR) is constant and in a certain period amount of dividend payments does not change both company is profit and loss, and 4) In anticipation of a shortage or excess of cash flow inventory with a dividend policy and fluctuations in level of profit and investment opportunities, if less first time company takes from current investment portfolio available.

There are four reasons underlying Myers (1984) in pecking order theory predicting that companies prioritize debt over equity when external funding is needed Siregar and Utama (2005), namely (1) market suffers losses due to information asymmetry between managers and market. Management tends to be interested in 
issuing new shares when overpriced while issuing new shares causes stock price to decrease; (2) Debt and shares both require transaction costs for company. However, debt transaction costs are relatively smaller when compared to stocks; (3) Companies get tax benefits by issuing debt securities. This tax benefit is obtained by company because of interest costs that can be charged as a deduction from taxable income; (4) Management control, in this case insider ownership, that is, ownership by management can be maintained if company issues debt securities.

\subsection{Hypothesis Development}

\subsubsection{Effect of Free Cash Flow on Debt Policy}

Managers are given power by owners of company, namely shareholders, to make decisions, which creates a potential conflict of interest known as agency theory (Brigham and Houston 2006, 126). In overcoming agency problems and reducing agency costs, it can be done with an internal control approach. This approach is carried out through a debt approach. Jensen (1986) states that debt can control excessive free cash flow by managers and can prevent companies from wasted investments.

Based on agency theory which states that market pressures encourage managers to distribute free cash flow to shareholders. Companies with large free cash flows that have high levels of debt reduce agency cost of free cash flow. This decrease reduced discretionary sources, especially cash flow under management control. When free cash flow is high company tends to use debt for its corporate funding activities (Jensen 1986) or in other words debt is used to increase amount of discretionary cash flow used to buy additional investment, pay off debt, buy treasury stock or simply add liquidity. Company. This shows that free cash flow has an influence on company's debt policy.

Indahningrum and Ratih (2009) stated that higher free cash flow, higher company's debt policy. This research is strengthened by Susilawati et al. (2012). Her research found that there is a significant positive influence between company's free cash flow on company's debt policy. With existence of debt can be used to control use of excessive free cash flow by managers.

Shareholders also enjoy more control over their management team, for example, if a company issues new debt and uses proceeds to repurchase outstanding ordinary shares, management must pay cash to cover this debt, simultaneously reducing amount of cash flow that is in management to play with. With this debt, management works more efficiently to avoid financial failures, thereby reducing agency costs for free cash flow. This is in accordance with theory of free cash flow capital structure (Keown et al. 2000).

Based on explanation above, it can be concluded that first hypothesis in this study is as follows:

H1: Free cash flow influences debt policy

\subsubsection{Effect of Management Ownership on Debt Policy}

Agency theory states that high agency costs result in a decline in value of company and are bad for shareholders. There are several alternatives that can be used to reduce agency costs, one of which is by increasing company's share ownership by management (Jensen and Meckling 1976). His analysis states that proportion of share ownership controlled by managers can influence company policies. In addition, 
management ownership aligns interests of management and shareholders, so that managers directly feel benefits of decisions taken correctly and feel losses as a consequence of worst decision making.

According to signaling theory is an action taken by company management that gives instructions to investors about how management views company's prospects. In Brigham and Houston (2001), companies with favorable prospects try to avoid sale of shares and seek every new capital needed by other means, including use of debt that exceeds target of normal capital structure. Companies with unfavorable prospects tend to sell their shares. Announcement of issuance of shares by a company is generally a signal that management views company's prospects as bleak. If a company offers to sell new shares more often than usual, then share price decreases, because issuing new shares means giving negative signals which can then suppress stock price even though company's prospects are bright.

Wahyuning (2007) stated that share ownership by management has a significant influence on debt policy. This is reinforced Susanto (2011) who stated that management ownership influences debt policy. Share ownership by management makes managers receive direct consequences from every decision made. Greater ownership of management, manager tends to try to improve its performance in interests of shareholders, including himself.

Based on explanation above, it can be concluded that second hypothesis in this study is as follows:

H2: Management ownership influences debt policy

\subsubsection{Effect of Dividend Policy on Debt Policy}

Dividends are part of profits provided to ordinary shareholders, either in cash or cash. Decision about how much profit is distributed to shareholders and how much is retained or reinvested, is called a dividend policy. Based on agency theory explains that dividends function as a means of monitoring management behavior and because they play a role in minimizing agency costs arising from potential conflicts of interest between shareholders (company owners) and agents (managers), on this basis market reacts positively / negatively to increases or decrease in dividends. In this context, companies that have high dividend payout ratios like funding with their own capital, thereby reducing agency costs. In addition, dividend payments can be made after obligation to pay interest and debt installments are fulfilled. Existence of these obligations makes managers more careful and efficient in using debt.

In summary, in pecking order theory there are several assumptions used that are strict dividend policies where management sets a constant amount of dividend payout and target dividend payout ratio (DPR) and within a certain period amount of dividend payment does not change whether company gains or losses.

Indahningrum and Ratih (2009) stated that dividend policy influences direction of company's debt policy predictions. This is reinforced by Susanto (2011) who stated that dividend policy influences debt policy. Cash dividend payments reduce sources of funds controlled by management such as debt. Companies that pay cash dividends indicate that company is able to finance investment opportunities without using external funding sources such as debt.

Based on explanation above, it can be concluded that second hypothesis in this study is as follows:

H3: Dividend policy influences debt policy 


\section{RESEARCH METHODS}

\subsection{Data}

Type of data used in this study is documentary data. Documentary data is a type of research data which includes invoices, journals, letters, and minutes of meetings, memos or in form of program reports (Indriantoro and Soepomo 1999, 146). Documentary data used in conducting this research is annual report of each manufacturing company listed on Indonesia Stock Exchange (IDX), which includes financial statements of manufacturing companies that have been published during research period.

In this study data source used is secondary data. Secondary data is a source of research data obtained indirectly through intermediary media (obtained and recorded by other parties) generally in form of evidence, notes or historical reports that have been compiled in archives (documentary data) which are published and not published (Indriantoro and Soepomo 1999, 147). Data source in this study is secondary data in form of financial statements of publications of manufacturing companies listed on Indonesia Stock Exchange.

\subsection{Population and Sample}

Population is a group of people, events or everything that has certain characteristics (Indriantoro and Soepomo 1999). Based on this understanding, study population can be understood as a group of individuals or objects of observation that have at least one characteristic in common. In this study, population are all manufacturing companies listed on Indonesia Stock Exchange (IDX).

According to in Dewanti, 2009 sample is a portion of population that has relatively same characteristics and is considered to represent population. Research sample was taken by purposive sampling where sample was chosen randomly whose information was obtained using certain considerations (Indriantoro and Soepomo 1999, 131). Sample selection considerations in this study are manufacturing companies listed on IDX that have following criteria.

1. Data on company's annual financial statements are available for 2012-2017 reporting year, respectively.

2. Company is not currently in a merger or acquisition, liquidation and delisting during observation. If company makes an acquisition or merger and experiences delisting during observation, variables in study will experience changes that are not comparable with previous period. If company experiences liquidation, research results are no longer useful because company is no longer in operation.

3. Companies that distribute dividends during observation year.

\section{RESULTS AND DISCUSSION}

\subsection{Research Object}

Based on data from Indonesia Stock Exchange number of manufacturing companies listed on Indonesia Stock Exchange in 2012 to 2017 recorded as many as 159 companies. Sample used in this study was selected based on purposive sampling method. Sample studied was 22 companies. List of companies included in sample can be seen in appendix 1 . 


\section{Table 1. Research Samples}

Manufacturing companies listed on IDX for period 2012-2017

Manufacturing companies for which company's annual financial statements are not available in succession for 2012-2017 reporting year.

Companies experiencing changes in business entities

Company that was found to have never distributed dividends during

observation year.

\begin{tabular}{lr}
\hline Number of companies that are objects of research & 22 \\
\hline Number of years of research & 6 \\
\hline Amount of data that can be tested & 132 \\
\hline
\end{tabular}

Source: processed data, 2020

\subsection{Descriptive Statistics}

Descriptive statistics are used to show amount of data used in this study and can show maximum value, minimum value, average value and standard deviation of each variable. Dependent variable used in this study is debt policy Independent variables used in this study include: Free cash flow, Management Ownership, Dividend Policy, and Company Size. Results of descriptive data processing can be seen in table 2 as follows:

Table 2. Descriptive Statistics

\begin{tabular}{lrrrr}
\hline \multicolumn{1}{c}{ Variable } & \multicolumn{1}{c}{ Minimum } & \multicolumn{1}{c}{ Maximum } & \multicolumn{1}{c}{ Average } & \multicolumn{1}{c}{$\begin{array}{c}\text { Deviation } \\
\text { Standard }\end{array}$} \\
\hline ABK & $-2,33 \mathrm{E} 7$ & $3,16 \mathrm{E} 6$ & $-1,6092 \mathrm{E} 6$ & $4,25320 \mathrm{E} 6$ \\
INSDR & 0,03 & 98,18 & 49,7103 & 37,50739 \\
DIV & 0,10 & 122,77 & 41,8792 & 31,43897 \\
FIRM SIZE & 5,56 & 8,19 & 6,5747 & 0,62172 \\
DR & 5,07 & 90,36 & 42,6003 & 21,26948 \\
\hline
\end{tabular}

Source: processed data, 2020

Table 2 shows that amount of data in this study were 132 samples. Debt policy variable, which is proxies by DR (debt ratio), has an average calculation of 42.60, meaning that average use of debt during 2012-2017 period is 42,60 per year. Standard deviation of debt policy variable is 21.26, meaning that for 6 (six) observation period, debt policy variable in manufacturing companies that went public on Indonesia Stock Exchange deviates from average of 21.26. If standard deviation value is smaller than calculated mean value, then calculated mean value can be used as a representation of entire data under study. Conversely, if standard deviation value is greater than calculated mean value, then calculated mean value cannot be used as a representation of entire data under study.

Lowest debt usage (minimum) during observation period is 5.07. Use of highest debt (maximum) during observation period is 90.36. Descriptive statistical results above also show that of 132 samples of free cash flow variables proxied by ABK, they have a calculated average of - 1.6092E6 over 2012-2017 period. Standard deviation of free cash flow variable is 4.25320E6, meaning that for 6 (six) observation period, free cash flow variable in manufacturing companies that went public on Indonesia Stock Exchange deviates from average of 4.25320E6. If standard 
deviation value is smaller than calculated mean value, then calculated mean value can be used as a representation of entire data under study. Conversely, if standard deviation value is greater than calculated mean value, then calculated mean value cannot be used as a representation of entire data under study. Use of lowest free cash flow (minimum) during observation period is -2.33E7. Highest debt usage (maximum) during observation period is 3.16E6.

Data of management ownership variables that are proxied by valid, have an average count of 49.7103 during 2012-2017 period. Standard deviation of management ownership variable is 37.50739 meaning that for 6 (six) period, management ownership variable in manufacturing companies that went public on Indonesia Stock Exchange deviates from average of 37.50739. If standard deviation value is smaller than calculated mean value, then calculated mean value can be used as a representation of entire data under study. Conversely, if standard deviation value is greater than calculated mean value, then calculated mean value cannot be used as a representation of entire data under study. Use of lowest debt (minimum) during observation period is 0.03 . Highest debt usage (maximum) during observation period is 98.18 .

Dividend policy variables that are proxied by DIV. Average count of 41.8792 for period 2012-2017. Standard deviation of dividend policy variable is 31.43897 , meaning that for 6 (six) observation period, dividend policy variable in manufacturing companies that went public on Indonesia Stock Exchange deviated from average of 31.43897. Lowest debt usage (minimum) during observation period is 0.10. Highest debt usage (maximum) during observation period is 122.77.

Company size variables that are proxied by firm size. Average count of 6.5747 for period 2012-2017. Standard deviation of firm size variables is 0.62172 , meaning that for 6 (six) observation period, company size variables in manufacturing companies that went public on Indonesia Stock Exchange deviated from average of 0.62172. Use of lowest debt (minimum) during observation period is 5.56. Use of highest debt (maximum) during observation period is 8.19.

\subsection{Hypothesis Testing}

This study uses multiple linear regression analysis because analysis is used to measure effect of more than one independent variable on one dependent variable (Ghozali 2005). To test hypotheses with multiple regression analysis. Testing multiple linear regression analysis is useful to determine level of influence of independent variables (free cash flow, management ownership, dividend policy and firm size) on dependent variable (debt policy).

\subsubsection{Determination Coefficient $(\mathrm{R} 2)$}

Coefficient of determination (R2) serves to see extent to which all independent variables can explain dependent variable. Value of coefficient of determination is between 0 and 1 . If number of coefficient of determination is getting stronger, which means independent variables provide almost all information needed to predict dependent variable variations. While value of coefficient of determination (adjusted R2) is small means that ability of independent variables in explaining variation of dependent variable is limited (Ghozali, 2006: 38). 
Table 3. Determination Coefficient Test Results (R2)

\begin{tabular}{rccl}
\hline R & R Square & Adjusted R Square & Std. Error of Estimate \\
\hline $0,495 \mathrm{a}$ & 0,245 & 0,196 & 19,07167 \\
\hline
\end{tabular}

Source: processed data, 2020

Based on test results of coefficient of determination in table 3 above, value of adjusted R2 in manufacturing company's regression model was obtained at 0.196. This shows that influence of independent variables, namely free cash flow, management ownership, dividend policy, and company size on debt policy dependent variable that can be explained by this equation is $19.6 \%$. While remaining $80.4 \%$ is influenced by other factors not included in regression model. Besides that, it can be seen that $R 2$ value is 0.196 . If value of $R 2$ is close to 1 then independent variable is getting stronger effect on dependent variable.

\subsubsection{Regression Test Results}

T-test aims to determine effect of each independent variable partially on dependent variable. If $\mathrm{t}$-count is greater than $\mathrm{t}$ table $(\mathrm{t}$-count $>\mathrm{t}$ table) and significant value of $\mathrm{t}$-count is smaller than $\alpha: 5 \%(0.05)$, it means that there is a significant influence between independent variables partially with dependent variable. By using multiple linear regression analysis methods, following results are obtained:

Table 4. Linear Regression Test Results

\begin{tabular}{lrrr}
\hline Variable & Coeff. & \multicolumn{1}{c}{ S } & \multicolumn{1}{c}{ Sig. } \\
\hline Constant & $-46,845$ & $-1,511$ & 1,136 \\
ABK & $2,277 \mathrm{e}-6$ & 3,165 & 0,002 \\
INSDR & 0,138 & 2,123 & 0,038 \\
DIV & $-0,154$ & $-2,276$ & 0,026 \\
FIRM SIZE & 13,829 & 2,865 & 0,006 \\
\hline
\end{tabular}

Source: processed data, 2020

Based on table 4, magnitude of effect of each independent variable partially on dependent variable can be explained as follows: free cash flow, from hypothesis testing shows that $t$-count $>t$ table $(3.165>1.992)$ and significance level of 0.002 is smaller than significant level $\alpha$ : 5\% (0.05). Thus, hypothesis $\mathrm{H} 0$ is partially rejected and $\mathrm{H} 1$ is accepted. That is, free cash flow has a significant effect on debt policy. Regression coefficient of 2,277e-6 shows a positive relationship. That is, if there is a change in free cash flow of $1 \%$, debt policy has increased by $2,277 \mathrm{e}-6$.

In table 4 it is known that management ownership shows value of $\mathrm{t}$ count $>\mathrm{t}$ table $(2.123>1.992)$ and significance level of 0.038 is smaller than significant level $\alpha$ : $5 \%(0.05)$. Thus, hypothesis $\mathrm{H} 0$ is partially rejected and hypothesis $\mathrm{H} 2$ is accepted. That is, management ownership also has a significant influence on debt policy. Regression coefficient of 0.138 also shows a positive relationship. That is, if there is a change in management ownership structure by $1 \%$, debt policy has increased by 0.138 . 
Dividend policy variable shows value of $t$ count $<\mathrm{t}$ table $(-2,276>1.992102)$ and significance level of 0.026 is smaller than significant level $\alpha$ : $5 \%(0.05)$. Thus, hypothesis $\mathrm{H} 0$ is partially rejected and hypothesis $\mathrm{H} 3$ is accepted. That is, dividend policy has a significant influence on debt policy. Regression coefficient of -0.154 shows a negative relationship. That is, if there is a change in number of shareholders by $1 \%$, debt policy also decreased by -0.154 .

Company size variable as a control variable shows that $\mathrm{t}$ count $>\mathrm{t}$ table $(2.865>1.99)$ and significance level of 0.006 is smaller than significant level $\alpha: 5 \%$ (0.05). Regression coefficient of 13,829 shows a positive relationship. That is, if there is a change in structure of company size by $1 \%$, debt policy has increased by 13,829 .

A constant of $-46,845$ states that if independent variables are: free cash flow, management ownership, dividend policy, and company size are of fixed or constant value, then value of dependent variable that is debt policy is $-46,845$.

\subsubsection{Anova Test}

$\mathrm{F}$ test is done to test feasibility of model that must be done in linear regression. Provisions used are (Ghozali 2005). If probability $>0.05$, then $\mathrm{H} 0$ is rejected successfully and $\mathrm{Ha}$ is rejected b. If probability is <0.05, then $\mathrm{H} 0$ is successfully rejected and $\mathrm{Ha}$ is accepted.

Table 5. Anova Test Results

\begin{tabular}{lllllcc}
\hline & Sum of Squares & df & $\begin{array}{c}\text { Mean } \\
\text { Square }\end{array}$ & F & Sig. \\
\hline Regression & 7217.9 & 4 & 1804.4 & 4.96 & $0.002 * *$ \\
\hline
\end{tabular}

Source: processed data, 2020

Based on table 5, calculated $F$ value is 5.507 and table's $F$ value is 2.493. This means that F-count > F table $(4.961>2.493)$. And significance level is smaller than $\alpha: 5 \%(0.05)$, then it shows that $\mathrm{H} 0$ is rejected and $\mathrm{Ha}$ is accepted and regression model can be used to predict debt policy.

\subsection{Discussion}

\subsubsection{Effects of Free Cash Flow on Debt Policy}

Results of testing hypothesis of influence of free cash flow on debt policy shows that $\mathrm{t}$-count $>\mathrm{t}$ table $(3.165>1.992)$ and significance level of 0.002 is smaller than significant level $\alpha: 5 \%(0.05)$. Thus, hypothesis $\mathrm{H} 1$ is accepted. That is, free cash flow has a significant effect on debt policy. From table 4.7 above shows that influence of variable free cash flow (ABK) on debt policy (DR) has a positive value. That is, if there is an increase in free cash flow assuming other variables are constant, then it is followed by an increase in debt ratio of 2,277e-6 with a significant level of 0.002 smaller than significant level $\alpha$ : $5 \%(0.05)$. Hypothesis 1 in this study which states that free cash flow has a positive effect on debt policy received.

These results support agency theory which states that market pressures encourage managers to distribute free cash flow to shareholders. Companies with large free cash flows that have high levels of debt reduce agency cost of free cash flow. This decrease reduced discretionary sources, especially cash flow under 
management control. When free cash flow is high company tends to use debt for its corporate funding activities (Jensen 1986). In other words, debt is used to increase amount of discretionary cash flow that is used to buy additional investments, pay off debt, and buy treasury stock or simple additions to company liquidity. This shows that free cash flow has a positive influence on company's debt policy so that h1 can be accepted.

Findings in this study are in accordance with results of research conducted by Indahningrum and Ratih (2009), and Susilawati et al. (2012), but contrary to results of research conducted by Hasugian (2010), Oktaria (2012), and Yudistira (2012) who prove that free cash flow has no effect on debt policy.

\subsubsection{Effect of Management Ownership on Debt Policy}

Results of testing hypothesis of influence of management ownership on debt policy that value of $t$-count $>t$ table $(2.123>1.992)$ and significance level of 0.038 is smaller than significant level $\alpha: 5 \%(0.05)$. Thus, hypothesis h0 is partially rejected and hypothesis $\mathrm{h} 2$ is accepted. That is, management ownership also has a significant influence on debt policy. From table 4.7 above shows that influence of management ownership variables (INSDR) on debt policy (DR) has a positive value. That is, if there is an increase in level of ownership of company's management assuming other variables are constant, then it is followed by an increase in debt ratio of 0.138 with a significant level of 0.038 less than significant level $\alpha$ : 5\% (0.05). Hypothesis 2 in this study which states that management ownership has an effect on debt policy is accepted.

Direction of relationship between management ownership and debt policy is positive. Direction of a positive relationship indicates that higher level of share ownership by management causes an increase in corporate debt. According to signaling theory is an action taken by company management that gives instructions to investors about how management views company's prospects. In (Brigham and Houston 2001), companies with favorable prospects try to avoid sale of shares and seek every new capital needed by other means, including use of debt that exceeds normal capital structure target.

Companies with unfavorable prospects tend to sell their shares. Announcement of issuance of shares by a company is generally a signal that management views company's prospects as bleak. If a company offers to sell new shares more often than usual, then share price decreases, because issuing new shares means giving negative signals which can then suppress stock price even though company's prospects are bright.

Results of this study are in line with research conducted by Wahyuning (2007), Susanto (2011) and Yudistira (2012) but not in accordance with research conducted by Indahningrum and Ratih (2009), Yeniatie and Nicken (2010) and Susilawati et al. (2012) which state that management ownership is not influences debt policy.

\subsubsection{Effects of Dividend Policy on Debt Policy}

Results of testing hypothesis of effect of dividend policy on debt policy that calculated $t$ value $<t$ table $(-2,276>1.992)$ and significance level of 0.026 is smaller than significant level $\alpha$ : 5\%(0.05). Thus, hypothesis 3 is accepted. That is, dividend policy has a significant influence on debt policy. From table 4 above shows that 
influence of dividend policy (DIV) variable on debt policy (DR) has a negative value. That is, if there is an increase in company's dividend policy assuming other variables are constant, then it is followed by a decrease in debt ratio of -0.154 with a significant level of 0.026 smaller than significant level $\alpha$ : 5\% (0.05). Hypothesis 3 which states that dividend policy affects debt policy is accepted.

Based on agency theory explains that dividends function as a means of monitoring management behavior and because they play a role in minimizing agency costs arising from potential conflicts of interest between shareholders (company owners) and agents (managers), on this basis market reacts positively / negatively to increases or decrease in dividends. In this context, companies that have high dividend payout ratios like funding with their own capital, thereby reducing agency costs. In addition, dividend payments can be made after obligation to pay interest and debt installments are fulfilled. Existence of these obligations makes managers more careful and efficient in using debt.

In summary, in pecking order theory there are several assumptions used that are strict dividend policies where management sets a constant amount of dividend payout and target dividend payout ratio (DPR) and within a certain period amount of dividend payment does not change whether company gains or losses. A stable dividend policy causes company to have to provide a certain amount of funds to pay fixed amount of dividend. Companies reduce dividend payments because most of profits are used to pay interest and loan repayments. Dividend payments can be made after interest payment obligations and debt installments are fulfilled. Existence of these obligations, making managers more careful and efficient in using debt.

Results of this study are in line with research conducted by Wahyuning (2007), Indahningrum and Ratih (2009), and Susanto (2011) but not in accordance with research conducted by Yeniatie and Nicken (2010), Susilawati et al. (2012) which states that dividend policy has no effect on debt policy.

\section{CONCLUSIONS AND SUGGESTIONS}

\subsection{Conclusion}

This study aims to determine and test effect of free cash flow, management ownership, dividend policy on debt policy partially. Based on data analysis and discussion described in Chapter 4, following conclusions can be made:

1. Free cash flow has a positive and significant impact on debt policy. Companies with large free cash flows that have high levels of debt reduce agency cost of free cash flow. This decrease reduced discretionary sources, especially cash flow under management control. When free cash flow is high company tends to use debt for its corporate funding activities.

2. Management ownership has a positive and significant influence on debt policy. According to signaling theory, companies with favorable prospects try to avoid sale of shares and seek every new capital needed by other means, including use of debt that exceeds normal target capital structure.

3. Dividend policy has a negative and significant effect on debt policy. In summary, in pecking order theory there are a number of assumptions used that are strict dividend policies where management determines amount of dividend payments and target dividend payout ratio (DPR) which is constant and in certain periods amount of dividend payments does not change whether company profits or losses. A stable dividend policy causes company to have to provide a certain 
amount of funds to pay fixed amount of dividend. Company reduces dividend payments because most of profits are used to pay interest and loan repayments. Dividend payments can be made after interest payment obligations and debt installments are fulfilled. Existence of these obligations, making managers more careful and efficient in using debt.

\subsection{Suggestions}

Researchers in conducting research there are several limitations that can later be used as material for consideration for subsequent research. Some of these limitations include following:

1. Period used in this study is only in form of three-year financial statements, namely 2012-2017. Expanding observation period, by expanding this observation period it is certain that research is more consistent.

2. Object of research is limited to manufacturing companies, not including all companies listed on Indonesia Stock Exchange. It is better if research is not only on manufacturing companies, it is better if other sector companies are also included in research.

3. Components used are only free cash flow, management ownership, and dividend policy and company size while results of coefficient of determination test (R2) note that there are still other variables that affect Debt Policy that is equal to $80.4 \%$. Adding other variables that might affect debt policy such as Institutional ownership, profitability, asset structure, and company growth.

\section{REFERENCES}

Brigham, E. F., and J. F. Houston. 2001. Manajemen Keuangan. Jakarta: Penerbit Erlangga.

2006. Dasar-Dasar Manajemen Keuangan. Vol. Buku 2. Jakarta: Penerbit Salemba Empat.

Faisal. 2004. Analisis Agnecy Cost, Struktur Kepemilikan, dan Mekanisme Corporate Governance. Simposium Nasional Akuntansi (SNA) VIII. Solo, 15 16 September 2005:197-208.

Ghozali, I. 2005. Aplikasi Analisis Multivariate dengan SPSS. Semarang: Badan Penerbit UNDIP.

Hasugian, C. 2010. Pengaruh Free Cash Flow dan Profitabilitas Terhadap Kebijakan Utang yang Terdapat di PT PERKEBUNAN NUSANTARA III (Persero) Medan. Skripsi, Fakultas Ekonomi, Universitas Sumatera Utara, Sumatera Utara.

Indahningrum, R. P., and H. Ratih. 2009. Analisis Pengaruh Free Cash Flow, Kepemilikan Institusional, dan Profitabilitas Terhadap Kebijakan Utang (Studi pada Perusahaan Manufaktur yang Terdaftar di BEI Tahun 20092011). Jurnal Bisnis dan Akuntansi 11 (3):189-207.

Indriantoro, N., and B. Soepomo. 1999. Metode Penelitian Bisnis untuk Akuntansi dan Manajemen. Yogyakarat: Badan Penerbit Fakultas Ekonomi Universitas Gadjah Mada. 
Jensen, M., C., and W. H. Meckling. 1976. Theory of Firm: Managerial Behaviour, Agency Cost, and Ownership Structure. Journal of Financial Economic 3 (1):305-360.

Jensen, M. C. 1986. The Agency Costs of Free Cash Flow, Corporate Finance, and Take Overs. AEA Paper and Proceedings 76 (2):659-655.

Keown, A. J., J. D. Martin, J. W. Pretty, and D. F. Scoot. 2000. Dasar-Dasar Manajemen Keuangan. Vol. Buku 2. Jakarta: Penerbit Salemba Empat.

Masdupi, E. 2005. Analisis Dampak Struktur Kepemilikan Pada Kebijakan Utang Dalam Mengontrol Konflik Keagenan. Jurnal Ekonomi dan Bisnis Indonesia 20 (1):57-69.

Mayangsari. 2003. Analisis Pengaruh Independensi, Kualitas Audit, serta Mekanisme Corporate Governance terhadap Integritas Laporan Keuangan. Simposium Nasional Akuntansi (SNA) VI:1255-1273.

Myers, S. 1984. Capital Structure Puzzle. Journal of Finance 39:92-575.

Oktaria, P. S. 2012. Pengaruh Rasio Free Cash Flow to Total Assets, Kepemilikan Institusional, dan Ukuran Perusahaan terhadap Kebijakan Utang pada Perusahaan Manufaktur di Bursa Efek Indonesia. Skripsi, Fakultas Ekonomi Universitas Negeri Yogyakarta, Yogyakarta.

Siregar, S. V. N. P., and S. Utama. 2005. Pengaruh Struktur Kepemilikan, Ukuran Perusahaan dan Praktek Corporate Governance terhadap Pengelolaan Laba. Simposium Nasional Akuntansi VII 9 (3):307-326.

Susanto, Y. K. 2011. Kepemilikan Saham, Kebijakan Dividen, Karakteristik Perusahaan, Risiko Sistimatik, Set Peluang Investasi dan Kebijakan Utang. Jurnal Bisnis dan Akuntansi 13 (3):195-210.

Susilawati, C. D. K., L. Agustina, and S. Tin. 2012. Faktor-Faktor yang Memengaruhi Kebijakan Utang Perusahaan Manufaktur yang Terdaftar di Bursa Efek Indonesia. Jurnal Keuangan dan Perbankan 16 (2):178-187.

Wahidahwati. 2002. Pengaruh Kepemilikan Manajemen dan Kepemilikan Institusional pada Kebijakan Utang Perusahaan: Sebuah Perspektif Theory Agency. Jurnal Riset Akuntansi Indonesia 5 (1):1-16.

Wahyuning, K. 2007. Pengaruh Struktur Kepemilikan Terhadap Kebijakan Utang Perusahaan (Studi Pada Perusahaan Textile/Garments di Bursa Efek Jakarta). Tesis, Program Pasca Sarjana Program Studi Magister Sains Akuntansi, Universitas Diponegoro, Semarang.

Yeniatie, and D. Nicken. 2010. Faktor-Faktor Yang Mempengaruhi Kebijakan Utang Pada Perusahaan NonKeuangan Yang Terdaftar Di Bursa Efek Indonesia. Jurnal Bisnis dan Akuntansi 12 (1):1-16.

Yudistira, F. I. 2012. Analisis Pengaruh Free Cash Flow dan Kepemilikan Manajemen Terhadap Kebijakan Utang pada Perusahaan Automotive \& Allied Product yang Terdaftar di Bursa Efek Indonesia. Skripsi, Departemen Akuntansi Fakultas Ekonomi, Universitas Sumatera Utara, Sumatera Utara. 


\section{APPENDIX}

\section{Companies Sample}

\begin{tabular}{llc}
\hline No & \multicolumn{1}{c}{ Companies } & Kode \\
\hline 1 & Asahimas Flat Glass Tbk & AMFG \\
2 & Tembaga Mulia Semanan Tbk & TBMS \\
3 & Charoen Pokphand Indonesia Tbk & CPIN \\
4 & Pabrik Kertas Tjiwi Kimia Tbk & TKIM \\
5 & Gudang Garam Tbk & GGRM \\
6 & Mustika Ratu Tbk & MRAT \\
7 & Mandom Indonesia Tbk & TCID \\
8 & Unilever Indonesia Tbk & UNVR \\
9 & Berlina Tbk & BRNA \\
10 & Astra Auto Part Tbk & AUTO \\
11 & Kimia Farma Tbk & KAEF \\
12 & Indocement Tunggal Prakarsa Tbk & INTP \\
13 & Astra International Tbk & ASII \\
14 & Indo Kordsa Tbk & BRAM \\
15 & Hanjaya Mandala Sampoerna Tbk & HMSP \\
16 & Selamat Sempurna Tbk & SMSM \\
17 & Temp Scan pasific Tbk & TSPC \\
18 & Arwana Citra Mulia Tbk & ARNA \\
19 & Fajar Surya Wisesa Tbk & FASW \\
20 & Goodyear Indonesia Tbk & GDYR \\
21 & Multistrada Arah Sarana Tbk & MASA \\
22 & Multi Bintang Indonesia Tbk & MLBI \\
\hline
\end{tabular}

